https://doi.org/10.19195/2082-8322.14.1

Tomasz Łukasz Nowak

ORCID: 0000-0003-3105-8013

Uniwersytet Wrocławski

\title{
Wykluczenia, przemilczenia, nierówności. Wstęp
}

In the animal kingdom, the rule is, eat or be eaten; in the human kingdom, define or be defined ${ }^{1}$.

W plebiscycie na Młodzieżowe Słowo Roku 2019 częściej od jednostek zwycięskich (alternatywka, jesieniara, eluwina ${ }^{2}$ ) zgłaszano leksem p0lka - zapisywany małą literą i z zerem w miejscu „o”, będący pogardliwym określeniem „kobiety roszczeniowej, której publiczne zachowanie przynosi wstyd"3. Co więcej, wśród nadesłanych wówczas propozycji przeważały te opisujące dziewczyny i młode matki, „często z lekką drwiną lub niechęcią"4 . Bartek Chaciński, jeden z jurorów plebiscytu, powodów takiego stanu rzeczy doszukiwał się wtedy szczególnie w działaniach mężczyzn, którzy wykorzystują wirtualną przestrzeń do tego, by narzekać na kobiety, obrażać je, a nierzadko wprost nawoływać do nienawiści i przemocy. Ci internauci nazywają siebie przegrywami, stulejarzami i, coraz częściej, incelami ${ }^{5}$.

1 T. Szasz, The Second Sin, New York 1973, s. 20.

2 Zob. „Alternatywka” Młodzieżowym Słowem Roku 2019!, https://sjp.pwn.pl/mlodziezowe-slowo-roku/Rozstrzygniecie-plebiscytu;202299.html (dostęp: 10.01.2021).

3 Zob. Rozstrzygnięcie plebiscytu MSR 2019 - komentarz Marka Łazińskiego, https://sjp.pwn.pl/mlodziezowe-slowo-roku/haslo/Rozstrzygniecie-plebiscytu-mlodziezowe-slowo-roku-2019-komentarzMarka-Lazinskiego;6831654.html (dostęp: 10.01.2021).

${ }^{4}$ Rozstrzygnięcie plebiscytu MSR 2019 - komentarz Bartka Chacińskiego, https://sjp.pwn.pl/mlodziezowe-slowo-roku/haslo/Rozstrzygniecie-plebiscytu-mlodziezowe-slowo-roku-2019-komentarzBartka-Chacinskiego;6831656.html (dostęp: 10.01.2021).

${ }^{5}$ Leksem incel również był zgłaszany do plebiscytu — zarówno w 2019, jak i w 2020 roku. Zob. ibidem oraz Julka, czyli język wojny płci, https://sjp.pwn.pl/mlodziezowe-slowo-roku/haslo/Julka-czyli-jezyk-wojny-plci;6952038.html (dostęp: 10.01.2021). 
Minął rok. Jeszcze przed wyborem Młodzieżowego Słowa Roku 2020 (a dokładnie przed informacją, że takiego wyboru nie będzie ${ }^{6}$ ) opublikowano komunikat jury o odrzuceniu w dalszych postępowaniach konkursowych zgłaszanego eponimu Julka/jul$k a^{7}$. Leksem ten, redefiniowany wraz z narastającymi w październiku polityczno-społecznymi napięciami, sprowadzono ostatecznie do przerysowanego i lekceważącego przedstawiania młodych aktywistek, działających (przede wszystkim) w mediach społecznościowych. Przesyłane na konkurs jednorodne semantycznie i negatywnie wartościujące definicje deprecjonowały zaangażowane politycznie i/lub społecznie kobiety, podkreślając przy tym, iż te „mówią (za) dużo, a wiedzą (za) mało”. Problemem jest tu jednak nie tylko nazywanie czy określanie, ale już przezywanie jednostki - w tym przypadku w związku z jej poglądami i wyznawanymi wartościami, które niechybnie prowadzi do kolejnego wykluczenia, pogłębiania mowy nienawiści i agresji, zarówno psychicznej, jak i fizycznej:

W sytuacji, w której wyśmiewane „julki” są bite na ulicach, kapituła plebiscytu na mocy regulaminu zdecydowała, że nie wygra słowo wyśmiewające czyjeś poglądy. Nie będziemy przemilczać tych zgłoszeń, ale w statystyce wyników nie uwzględnimy słów zaostrzających konflikt społeczny ${ }^{8}$.

Minął rok. Rok od polki do julki. Rok od medialnych dyskusji o feminatywach i w efekcie wydania o tychże opinii Rady Języka Polskiego (RJP) w listopadzie 2019 $\mathrm{roku}^{9}$ do równie głośnych dyskusji o słowie Murzyn po opublikowanej w sierpniu 2020 opinii członka RJP Marka Łazińskiego ${ }^{10}$. Minął rok od dołączenia do lipcowego numeru „Gazety Polskiej” naklejek z napisem „Strefa wolna od LGBT”11 do (po

6 „Kapituła plebiscytu Młodzieżowe Słowo Roku postanowiła w roku 2020 nie wyłaniać zwycięskiego słowa. Konkurs, który przez lata był zabawą z językiem i służył refleksji nad nim, stał się w tym roku areną walki na słowa, a tego faktu nie możemy i nie chcemy akceptować. Najczęściej zgłaszane były słowa wulgarne, wyśmiewające konkretne osoby, poglądy, postawy lub płeć [...]”. Zob. Komunikat kapituły plebiscytu na Młodzieżowe Słowo Roku 2020, https:/sjp.pwn.pl/mlodziezowe-slowo-roku/haslo/ Komunikat-kapituly-plebiscytu-na-Mlodziezowe-Slowo-Roku-2020;6952261.html (dostęp: 10.01.2021).

7 Zob. Stanowisko kapituly plebiscytu w sprawie słowa Julka/julka, https://sjp.pwn.pl/mlodziezowe-slowo-roku/haslo/Stanowisko-kapituly-plebiscytu-w-sprawie-slowa-Julka-julka;6952037.html (dostęp: 10.01.2020).

8 Ibidem.

9 Zob. Stanowisko Rady Języka Polskiego przy Prezydium PAN w sprawie żeńskich form nazw zawodów i tytułów (25 XI 2019 r.), https://rjp.pan.pl/index.php?option=com_content\&view=article\&i$\mathrm{d}=1861$ :stanowisko-rjp-w-sprawie-zenskich-form-nazw-zawodow-i-tytulow\&catid=98\&Itemid=81 (dostęp: 10.01.2021).

10 „Murzyn” $i$ „Murzynka”, https://rjp.pan.pl/index.php?option=com_content\&view=article\&id= 1892: murzyn-i-murzynka\&catid=44\&Itemid=208 (dostęp: 10.01.2021). Notabene napięcia wokół opinii Marka Łazińskiego ciekawie podsumował i skomentował Mateusz Adamczyk na swoim vlogu w materiale Czy RJP uznała słowo MURZYN za obraźliwe?, https://youtu.be/xN2pnre7rQo (dostęp: 10.01.2021). Zob. również D. Garbicz-Stodolna, Doświadczenie politycznej poprawności a grzeczność językowa, „Dziennikarstwo i Media” 13, 2020, s. 72-74.

11 Należy przypomnieć, że sąd nakazał wydawcy usunięcie z dystrybucji naklejek z tym hasłem, porównując je do działań propagandowych III Rzeszy, podkreślając zarazem, iż „[r]ozprzestrzenianie

Dziennikarstwo i Media 14, 2020

(C) for this edition by CNS 
pierwsze) kampanii prezydenckiej 2020, podczas której z ust jednego z kandydatów (obecnie już Prezydenta) padały homofobiczne słowa, na przykład „Próbuje się nam [...] wmówić, że [LGBT] to ludzie, a to jest po prostu ideologia”, oraz (po drugie) do czerwcowego programu na antenie TVP Info, w którym inny polityk (a obecnie Minister Edukacji i Nauki) powiedział: „Brońmy nas przed ideologią LGBT i skończmy słuchać tych idiotyzmów o jakichś prawach człowieka czy jakiejś równości. Ci ludzie nie są równi ludziom normalnym".

Język kształtuje rzeczywistość. Nie tylko ją opisuje, ale również tworzy. To, w jaki sposób autor(ka) przekazu dobierze słowa, jak je połączy, w jakim kontekście ich użyje, wpłynie na to, jaki świat zobaczą odbiorcy tej wypowiedzi i jak go ocenią. Jakie zajmą stanowisko. I w końcu - co zrobią? Dlatego tak istotne są świadomość języka, wrażliwość oraz to, co w retoryce nazywa się stosownością. Ta z kolei jest warunkiem sine qua non kompetencji komunikacyjnej, którą powinna się wyróżniać każda osoba publicznie zabierająca głos.

Tymczasem nawet $\mathrm{z}$ ambony dało się słyszeć wyrażenia dehumanizujące wybrane grupy społeczne. Konstrukcje wyrazowe sprowadzające człowieka oraz to, co z jego człowieczeństwem się łączy, do „ideologii” czy dodatkowo biologizująca osoby ze społeczności LGBT+ „tęczowa zaraza” to tylko niektóre z deprecjonujących elementów retoryki „dobrej zmiany”, powielanych w publicznym dyskursie minionego roku. Co więcej, w obliczu pandemii wywołanej wirusem SARS-CoV-2 pojawiły się w mediach kolejne konstrukcje Obcego, podszyte między innymi ksenofobią czy częściej wprost sinofobią. Jak bowiem zauważył Michał Wróblewski, jedną z reakcji na to, co nieznane, a przy tym dowodnie niebezpieczne (w tym przypadku potwierdzone codziennymi doniesieniami dotyczącymi liczby zgonów) — reakcji, która niezmiennie powtarza się w obliczu różnych epidemii/pandemii, jest właśnie stygmatyzacja i przypisywanie odpowiedzialności za zaistniałe zdarzenia wybranym grupom społecznym, narodowościowym itd.:

Już w średniowieczu za słynną Czarną Śmierć, czyli epidemię dżumy, obarczano Żydów, oskarżając ich o zatruwanie studni. Z kolei podczas epidemii HIV/AIDS środowiska mniejszości seksualnych odgrywały rolę kozła ofiarnego, kiedy używano wobec nich religijnych i silnie nacechowanych moralnie metafor. [...] Dla Niemców syfilis był „francuską chorobą”, z kolei dla Francuzów „włoską chorobą”. Przy okazji pandemii wirusa H1N1 w amerykańskich mediach pojawiało się określenie „meksykańska grypa"12.

Wyrażenia „chiński wirus”, „zabójcza choroba z Chin” czy „grypa z Wuhan” to zatem kolejne przykłady biologizacji, które rozbudzając sinofobiczne (a z czasem ogólnie

naklejek oraz zachęcanie do ich umieszczania w przestrzeni publicznej jest równoznaczne z zachęcaniem do tworzenia stref wykluczenia, mobbingu, a w skrajnych przypadkach do tworzenia swoistych gett”. Zob. Wolne Sady na Facebooku, https://www.fb.com/WolneSady/photos/2160210167619627 (dostęp: 10.01.2021).

12 M. Wróblewski, Superroznosiciele wątpliwości. Sceptycyzm i teorie spiskowe $w$ dobie koronawirusa, „Dyskurs \& Dialog” 2020, nr 6, s. 26-27. 
ksenofobiczne czy wręcz rasistowskie) nastroje, doprowadziły do naznaczenia i społecznych niechęci, a finalnie do agresywnego zachowania wobec Chinek/Chińczyków ${ }^{13}$ oraz - jak na przykład w Hiszpanii ${ }^{14}$ - innych mniejszości narodowych. Ale nie tylko. Obecny w polskim dyskursie publicznym język wojny i język st rachu doprowadził do stygmatyzacji niektórych grup zawodowych. Z aktami nienawiści musieli zmierzyć się więc między innymi pracujący w szpitalach lekarze/lekarki i pielęgniarze/pielęgniarki. Doświadczali oni nie tylko hejtu zwerbalizowanego w sieci, ale - jak donosiły media - niektórych $\mathrm{z}$ nich wypraszano nawet $\mathrm{z}$ osiedlowych sklepów, niszczono im zaparkowane przed domem samochody czy podrzucano ulotki, w których „sugerowano” przeprowadzkę ${ }^{15}$.

Przykładów stygmatyzacji, wykluczenia, nierówności (niestety) wcale nie ubywa. Autorki i autorzy artykułów publikowanych w 14. tomie „Dziennikarstwa i Mediów” wzięli więc na tapet tematy niełatwe, ale niezwykle ważne; społecznie i kulturowo (a przy tym językowo i komunikacyjnie) istotne. Aleksandra Kumala omówiła przejawy manipulowania pamięcią o homoseksualnych więźniach obozów koncentracyjnych. Autorka wskazała między innymi na dyskursywne wykluczenie tej grupy „zapomnianych ofiar nazizmu” oraz praktykę fałszywego utożsamiania zjawiska obozowej przemocy seksualnej ze zjawiskiem obozowego homoseksualizmu jako takiego. Trzeba bowiem przypomnieć, że do wykluczenia i nierówności prowadzą nie tylko nazwy czy przezwania. Również „[m]ilczenie to symptom trwałej hierarchii cierpienia, opartej na przekonaniu o tym, że nie wszystkim wolno należeć do doborowego towarzystwa ofiar i bohaterów"16.

Bartosz Cudak pochylił się nad zjawiskiem dyskryminacyjnej retoryki (na przykładzie „dobrej zmiany”), której sprawczy i performatywny charakter prowadzi w efekcie między innymi do przejścia (z)realizowanego aktu mowy w zagrażające osobom spoza heteromatriksa zachowania. Artur Stęplewski omówił natomiast zagadnienie medialnych manipulacji, których bezpośrednim celem jest dyskredytacja Kemala Paszy Atatürka. Luki w jego biografii służą współczesnym za przesłanki do (s)twierdzenia, że Atatürk mógł być gejem. Na przykładzie wybranych greckich

13 „Od czasu pojawienia się w mediach informacji o Covid-19 wzrosła w USA liczba fizycznych napaści oraz innych aktów dyskryminacji skierowanych przeciwko Azjatom i Amerykanom azjatyckiego pochodzenia”. Zob. J. deCook, Teorie spiskowe, dezinformacja i ksenofobia: skrajna prawica wobec koronawirusa, https://krytykapolityczna.pl/swiat/teorie-spiskowe-dezinformacja-i-ksenofobia-skrajnaprawica-wobec-koronawirusa/ (dostęp: 10.01.2021).

14 Rasizm w czasach pandemii, https://www.liberties.eu/pl/news/rasizm-w-czasach-pandemii/18949 (dostęp: 10.01.2021). Zob. również M.A. Trzeciak, Dziennikarstwo naukowe w czasach zarazy i teorii spiskowych, „Dziennikarstwo i Media” 13, 2020, s. 38-41.

15 A. Woźny, Szkic do medialnego portretu koronawirusa. Z medycyną narracyjna $w$ tle, „Dyskurs \& Dialog” 2020, nr 6, s. 10. Por. F. Brzeźniak, Epidemia strachu i wojenna mobilizacja. Pierwsze miesiące pandemicznego dyskursu publicznego w Polsce, „Dyskurs \& Dialog” 2020, nr 6, s. 81-85.

$16 \mathrm{~J}$. Ostrowska, Przemilczane. Seksualna praca przymusowa w czasie II wojny światowej, Warszawa 2018 , s. 9. 
i tureckich przekazów medialnych badacz wyjaśnił, w jaki sposób (i dlaczego) znak gay semantyzuje się tamże jako Obcy/Inny.

Łukasz Kiełpiński skoncentrował się na unikalnym, (bo) pozawerbalnym dyskursie grup wykluczonych, które wykształciły charakterystyczny dla siebie kod komunikacyjny, oparty na ciele, jego sposobach poruszania się oraz na estetycznych metamorfozach. Na warsztat wziął więc temat performansu rozumianego jako język ekspresji typowy dla osób z różnych względów nienormatywnych. $Z$ kolei Iz ab ella Tyborowicz poddała refleksji zagadnienie relacji jednostek obciążonych chorobą, szczególnie - właśnie - wykluczonych, z pozostałą częścią społeczeństwa. Wyjaśniła przy tym, czym jest zawarte w tytule jej artykułu "praktykowanie choroby”, które wymyka się klasycznemu pojęciu „chorowania”, obejmując swoim znaczeniem między innymi strategie podmiotu, którego decyzje i (w następstwie) zachowania pomagają zataić lub ujawnić otoczeniu (na własnych warunkach) swój stan zdrowia/ choroby.

Groznawca Grzegorz Zyzik z powodzeniem udowodnił, że gry wideo zaangażowane społecznie pomagają rozwiązywać problemy i docierać do ludzi z określonym przekazem w dyskursach dotyczących płci, seksualności, rasy czy w ogóle figury Obcego/Innego. Growe doświadczenia przygotowują bowiem do wnikliwszych oglądów rzeczywistości, dzięki czemu gracze mogą zająć krytyczną postawę wobec siebie i społeczeństwa, szczególnie że - jak zaznaczył Zyzik - współcześnie, w pewnym sensie, każdy skazany jest na autokreację, na improwizację i negocjowanie ze światem własnych dążeń i marzeń. Funkcję edukacyjną mogą (czy: mają szansę) pełnić również projekty i realizacje szeroko pojętej branży kreatywnej. Dla potwierdzenia Anna M. Kiełbiewska dokonała analizy retorycznej wybranych przekazów reklamowych, które odwołują się między innymi do kodeksów obyczajowych oraz zwyczajowych zachowań grzecznościowych. Ciekawy poznawczo artykuł stanowi przyczynek do dalszych badań kreatywnych realizacji reklamowych, marketingowych czy - szerzej - produktów brandingu i communication design z punktu widzenia grzeczności, ale też, w dalszej kolejności (na co piszący te słowa ma nadzieję), stosowności i wrażliwości w komunikacji.

Jedną z potrzeb człowieka jest potrzeba przynależności. A przynależymy do jakiejś grupy rówieśniczej, subkulturowej, zawodowej itp. wtedy, gdy wpisujemy się w ustalone ramy, spełniamy określone w tej społeczności „kryteria normalności”. Te z kolei dyscyplinują, skrajnie stają się narzędziem społecznej manipulacji. Kaja Wójcik podjęła się więc próby przedstawienia medialnego konstruktu kobiety dojrzałej, która - za słowami autorki artykułu - tkwi jakby w pułapce, zawieszona między swoimi możliwościami a oczekiwaniami publiczności, otrzymując wiele porad i wskazówek, które miałyby pomóc jej — czy aby na pewno? - się uwolnić.

Tradycyjnie w „Dziennikarstwie i Mediach” nie mogło zabraknąć naukowego debiutu. W ostatnim (w temacie dyskursów wykluczenia) artykule Robert Na rloch przedstawia fragment rzeczywistości gejów żyjących w latach dziewięćdziesiątych XX 
wieku, zapisany w opublikowanych wówczas tekstach w magazynie „MEN!”. Autor skoncentrował się na formacjach słowotwórczych z leksemem ciota i ciotka, które już w swojej konstrukcji podkreślają złożoność tożsamości homoseksualnych mężczyzn. Swoją analizę wpisuje zresztą między innymi w podstawowe założenia kampu, podkreślając ujęcie płci jako stylizacji, której indywidualną realizację wspierają językowe narzędzia.

W nowym tomie Czytelnicy/Czytelniczki znajdą także (zwerbalizowane) obserwacje i komentarze odnoszące się do tego, co „tu i teraz”, do aktualnych problemów politycznych, społecznych i kulturowych oraz zagadnień z obszaru mediów oraz (projektowania) komunikacji. Ufam, że teksty te - zarówno artykuły naukowe, jak i komentarze - poprowadzą Państwa do wielowymiarowych rozważań, głębokich refleksji, w efekcie skłonią do rozmowy, polemiki. W myśl, tak deficytowych w dyskursie publicznym, stosowności i wrażliwości. Z nadzieją na porozumienie.

\section{Bibliografia}

Adamczyk M., Czy RJP uznała słowo MURZYN za obraźliwe?, https://youtu.be/xN2pnre7rQo (dostęp: 10.01.2021).

„Alternatywka” Młodzieżowym Słowem Roku 2019!, https://sjp.pwn.pl/mlodziezowe-slowo-roku/Rozstrzygniecie-plebiscytu;202299.html (dostęp: 10.01.2021).

Brzeźniak F., Epidemia strachu i wojenna mobilizacja. Pierwsze miesiące pandemicznego dyskursu publicznego w Polsce, „Dyskurs \& Dialog” 2020, nr 6, s. 79-97.

deCook J., Teorie spiskowe, dezinformacja i ksenofobia: skrajna prawica wobec koronawirusa, https:// krytykapolityczna.pl/swiat/teorie-spiskowe-dezinformacja-i-ksenofobia-skrajna-prawica-wobeckoronawirusa/ (dostęp: 10.01.2021).

Garbicz-Stodolna D., Doświadczenie politycznej poprawności a grzeczność językowa, „Dziennikarstwo i Media" 13, 2020, s. 67-75.

Julka, czyli język wojny płci, https://sjp.pwn.pl/mlodziezowe-slowo-roku/haslo/Julka-czyli-jezyk-wojny-plci;6952038.html (dostęp: 10.01.2021).

Komunikat kapituły plebiscytu na Młodzieżowe Słowo Roku 2020, https://sjp.pwn.pl/mlodziezowe-slowo-roku/haslo/Komunikat-kapituly-plebiscytu-na-Mlodziezowe-Slowo-Roku-2020;6952261.html (dostęp: 10.01.2021).

„Murzyn” $i$ „Murzynka”, https://rjp.pan.pl/index.php?option=com_content\&view=article\&id=1892:m urzyn-i-murzynka\&catid=44\&Itemid=208 (dostęp: 10.01.2021).

Ostrowska J., Przemilczane. Seksualna praca przymusowa w czasie II wojny światowej, Warszawa 2018.

Rasizm w czasach pandemii, https://www.liberties.eu/pl/news/rasizm-w-czasach-pandemii/18949 (dostęp: 10.01.2021).

Rozstrzygnięcie plebiscytu MSR 2019 - komentarz Bartka Chacińskiego, https://sjp.pwn.pl/mlodziezowe-slowo-roku/haslo/Rozstrzygniecie-plebiscytu-mlodziezowe-slowo-roku-2019-komentarzBartka-Chacinskiego;6831656.html (dostęp: 10.01.2021).

Rozstrzygnięcie plebiscytu MSR 2019 - komentarz Marka Eazińskiego, https://sjp.pwn.pl/mlodziezowe-slowo-roku/haslo/Rozstrzygniecie-plebiscytu-mlodziezowe-slowo-roku-2019-komentarz-MarkaLazinskiego;6831654.html (dostęp: 10.01.2021). 
Stanowisko kapituly plebiscytu w sprawie słowa Julka/julka, https://sjp.pwn.pl/mlodziezowe-slowo-roku/haslo/Stanowisko-kapituly-plebiscytu-w-sprawie-slowa-Julka-julka;6952037.html (dostęp: 10.01.2020).

Stanowisko Rady Języka Polskiego przy Prezydium PAN w sprawie żeńskich form nazw zawodów i tytułów (25 XI 2019 r.), https://rjp.pan.pl/index.php?option=com_content\&view=article\&id=1861: stanowisko-rjp-w-sprawie-zenskich-form-nazw-zawodow-i-tytulow\&catid=98\&Itemid=81 (dostęp: 10.01.2021).

Szasz T., The Second Sin, New York 1973.

Trzeciak M.A., Dziennikarstwo naukowe w czasach zarazy i teorii spiskowych, „Dziennikarstwo i Media" 13,2020 , s. 35-49.

Wolne Sądy na Facebooku, https://www.fb.com/WolneSady (dostęp: 10.01.2021).

Woźny A., Szkic do medialnego portretu koronawirusa. Z medycyną narracyjna w tle, „Dyskurs \& Dia$\log$ " 2020, nr 6, s. 9-20.

Wróblewski M., Superroznosiciele wątpliwości. Sceptycyzm i teorie spiskowe $w$ dobie koronawirusa, „Dyskurs \& Dialog” 2020, nr 6, s. 23-40. 